\title{
Correlation of Age, Duration of Diabetes Mellitus, HbA1c Levels, and Erectile Dysfunctions in Type II Diabetes Mellitus
}

\author{
Niken Widyaningsih ${ }^{1}$, Dwi Nur Ahsani²,*
}

${ }^{1}$ Faculty of Medicine, Universitas Islam Indonesia, Yogyakarta, Indonesia

${ }^{2}$ Department of Histology, Faculty of Medicine, Universitas Islam Indonesia, Yogyakarta, Indonesia

*Corresponding author. Email: dwi.nurahsani@uii.ac.id

\begin{abstract}
Uncontrolled diabetes mellitus (DM) can cause erectile dysfunctions. A number of studies show that erectile dysfunctions (ED) are more common in a longer period of DM. Age and HbA1c levels are related to type II DM. This study aimed to reveal the correlation between age, duration of DM, HbA1c levels, and ED in type II DM. This was a cross-sectional study of 34 male patients with type II DM conducted in PROLANIS (Program Pengelolaan Penyakit Kronis/Chronic Disease Care Program) in Harjobinangun Village, Sleman, Yogyakarta. The erectile dysfunctions were assessed using the International Index of Erectile Function (IIEF-5) questionnaire. The HbA1c levels were measured from blood samples. All obtained data were analyzed in a Chi-square analysis with a $95 \%$ confidence interval. Of the total subjects, $70.6 \%$ were aged $>60$ years, $61.8 \%$ have had DM for more than 6 years, $64.1 \%$ had $\mathrm{HbA} 1 \mathrm{c}$ score $>6.5 \%$, and $44.1 \%$ were in moderate dysfunction. No correlations were found among the age $(\mathrm{p}=0.475)$, duration of DM $(\mathrm{p}=0.640)$, HbA1c levels $(\mathrm{p}=0.611)$, and ED. To sum up, here was no correlation between age, duration of DM, HbA1c levels, and ED in type II DM.
\end{abstract}

Keywords: Age, DM, HbAlc, IIEF-5

\section{INTRODUCTION}

Diabetes Mellitus (DM) is among the non-communicable diseases with an increasing number of patients each year [1]. Data from Indonesia Basic Health Research (RISKESDA) in 2013 indicated that the prevalence of DM in Indonesia had almost doubled compared to the data in 2007. In Indonesia, the proportion of DM is approximately $6.9 \%$ consisting of patients with impaired glucose tolerance (29.9\%) and impaired fasting blood glucose (36.6\%). Epidemiologically, it is estimated that the prevalence of DM in Indonesia can reach 21.3 million patients by 2030. Unfortunately, Yogyakarta has the highest prevalence of DM in Indonesia (2.6) which is far above the average (1.5) [2].

Type II DM generally occurs in old age. Insulin resistance in muscles and liver as well as the failure of pancreatic beta cells to secrete insulin have been recognized as the pathophysiology of the central damage of type II DM. Other pathogeneses such as increasing lipolysis, incretin deficiency, hyperglucagonemia, increasing absorption of glucose in the kidneys, and insulin resistance in the brain also contribute to impaired glucose tolerance in type II DM [3],[4]. Uncontrolled DM can lead to some complications, including ED in males. Sugiharso et al. stated that the prevalence of ED in type II DM reached 61.8\% [5].

HbA1c levels are one of the parameters which can be used to determine the levels of DM patient compliance. High levels of HbA1c can indicate that a patient is not compliant to regulate his/her blood glucose levels. In addition, this parameter can determine whether a patient experiences a phase of complications [6]. A study suggested that an incidence of complications can significantly increase in number in conjunction with elevated HbA1c levels. Fewer DM complications were found at $\mathrm{HbA1c}$ levels of $<6 \%$ compared with at $>7 \% \mathrm{HbA} 1 \mathrm{c}$ levels [7].

Other research reported a significant correlation between the duration for which patients experience DM and an incidence of ED. ED occurred to $63.3 \%$ patients who have been experiencing DM for 5-8 years while $36.7 \%$ patients with 1-4 years of DM also had ED [8]. There is only a limited number of studies indicating the correlation between age, duration of DM, HbA1c levels, and ED at primary facilities in Indonesia. Therefore, this study aims to examine the relationship between age, duration of $\mathrm{DM}, \mathrm{HbA} 1 \mathrm{c}$ levels, and ED in primary facilities. Research in primary facilities is deemed important since patients examined in these facilities have not shown any noticeable complications. By looking at the correlation between age, HbAlc levels, and incidence of ED in type II DM patients in primary facilities, an appropriate program to prevent the aggravation of DM conditions related to ED can be implemented. 


\section{METHODS}

\subsection{Research subjects}

This study has been approved by the Ethics Commission of the Faculty of Medicine, Universitas Islam Indonesia. This was a descriptive-analytic study with a cross-sectional design. The research was conducted in PROLANIS (Program Pengelolaan Penyakit Kronis/Chronic Disease Care Program), specifically in one of the primary health care facilities (family doctors) in Harjobinangun Village, Sleman, Yogyakarta. The inclusion criterion for the research subjects was male patients with type II DM joining PROLANIS. The diagnosis of DM was confirmed from the medical records in PROLANIS. Patients who were not willing to be a subject, refused to have blood tests of HbAlc levels, or did not want to complete the questionnaire were excluded from this study.

\subsection{Research questionnaire}

The questionnaire of this study consisted of general data (name, age, duration of DM), and questions adopted from the IIEF-5 questionnaire. Each of the general data was divided into a number of categories. The IIEF-5 questionnaire included 5 questions with the scores ranging from 1 to 5 . Patients should select the most appropriate score representing their sexual activities during the last 6 months. A total score of 22-25 indicated a normal condition (no erectile dysfunctions). Erectile dysfunctions were detected when the score in IIEF-5 was less than 22 (mild dysfunction: 17-21, mild to moderate dysfunction: $12-16$, moderate dysfunction: 8-11, and severe dysfunction: 5-7).

\subsection{Diagnosis of HbAlc Levels}

The diagnosis of HbAlc levels was conducted by examining venous blood samples from the median cubital veins. The amount of blood taken from each patient was approximately $3 \mathrm{ml}$. The diagnosis results were stated in 3 levels, namely $4-5.6 \%, 5.7-6.4 \%$, and $>6.5 \%$.

\subsection{Statistical analysis}

The data of this study included patient characteristics, $\mathrm{HbA1c}$ levels, and IIEF-5 scores all presented in percentage. The correlations between age and IIEF-5 scores, between DM duration and IIEF-5 scores, and between HbA1c levels and IIEF-5 scores were analyzed using the Chi-square test (95\% confidence interval and $\mathrm{p}<0.05$ ).

\section{RESULTS}

There were 125 DM patients participated in PROLANIS in the period of July 2018. Of 125 cases, 50 were men but only 34 patients met the inclusion criteria to be the subjects of this study. The respondents in this study were mainly elderly people aged more than 50 years old, with $70.6 \%$ respondents aged $>60$ years old. Most of the respondents have suffered from DM for quite a long time (>8 years at $61.8 \%$, Table 1).

Table 1. Characteristics of research subjects

\begin{tabular}{|c|c|c|}
\hline Characteristic & $\begin{array}{c}\text { Frequency } \\
(\mathbf{n})\end{array}$ & $\begin{array}{c}\text { Percentage } \\
(\%)\end{array}$ \\
\hline Sex & & 100 \\
Male & 34 & 0 \\
Female & 0 & \\
\hline Age (years old) & & 0 \\
$31-40$ & 0 & 2.9 \\
$41-50$ & 1 & 26.5 \\
$51-60$ & 9 & 70.6 \\
$>60$ & 24 & \\
\hline Duration of DM & & 23.5 \\
(years) & 8 & 14.7 \\
$1-4$ & 5 & 61.8 \\
\hline $5-8$ & 21 & \\
\hline$>8$ & &
\end{tabular}

Based on the HbA1C levels, it was found that most of the respondents had high $\mathrm{HbA1c}$ levels $(64.1 \%$ patients with HbAlc score of $>6.5 \%$ ). A majority of the respondents experienced ED problems as shown by the IIEF-5 scores. Only $8.8 \%$ respondents experienced no ED problems while almost half of them $(44.1 \%)$ had moderate ED (Table 2 ).

Table 2. Distribution of hba1c levels and iief-5 scores

\begin{tabular}{|l|c|c|}
\hline \multicolumn{1}{|c|}{ Distribution } & $\begin{array}{c}\text { Frequency } \\
(\mathrm{n})\end{array}$ & $\begin{array}{c}\text { Percentage } \\
(\%)\end{array}$ \\
\hline $\begin{array}{l}\text { HbA1c Level } \\
\text { 4-5.6\% }\end{array}$ & 0 & 0 \\
\hline $5.7-6.4 \%$ & 2 & 5.9 \\
\hline$>6.5 \%$ & 32 & 64.1 \\
\hline IIEF-5 Score & & \\
Normal & 3 & 8.8 \\
\hline Mild & 6 & 17.6 \\
\hline Mild-Moderate & 5 & 14.7 \\
Moderate & 15 & 44.1 \\
Severe & 5 & 14.7 \\
\hline
\end{tabular}

The older the respondents, the more ED conditions were found ( 21 respondents aged $>60$ experienced ED). Most of the ED conditions were moderate $(35.3 \%)$. No statistically significant correlation was found between age and IIEF-5 scores $(\mathrm{p}=0.476$, Table 3$)$. 
Table 3. Correlation between age and IIEF-5 scores

\begin{tabular}{|c|c|c|c|c|c|c|}
\hline \multirow[b]{2}{*}{ Age (years) } & \multicolumn{5}{|c|}{ IIEF-5 Score } & \multirow[b]{2}{*}{$p$} \\
\hline & $\begin{array}{c}\text { Normal } \\
\text { n }(\%)\end{array}$ & $\begin{array}{l}\text { Mild } \\
\text { n (\%) }\end{array}$ & $\begin{array}{c}\text { Mild- } \\
\text { Moderate } \\
\text { n (\%) }\end{array}$ & $\begin{array}{c}\text { Moderate } \\
\text { n (\%) }\end{array}$ & $\begin{array}{l}\text { Severe } \\
\text { n }(\%)\end{array}$ & \\
\hline $41-50$ & $0(0 \%)$ & $1(2.9 \%)$ & $0(0 \%)$ & $0(0 \%)$ & $0(0 \%)$ & \multirow{4}{*}{0.476} \\
\hline $51-60$ & $0(0 \%)$ & $2(5.9 \%)$ & $2(5.9 \%)$ & $3(8.8 \%)$ & $2(5.9 \%)$ & \\
\hline$>60$ & $3(8.8 \%)$ & $3(8.8 \%)$ & $3(8.8 \%)$ & $12(35.3 \%)$ & $3(8.8 \%)$ & \\
\hline Total (\%) & $3(8.8 \%)$ & $6(14.7 \%)$ & $5(14.7 \%)$ & $15(44.1 \%)$ & $5(14.7 \%)$ & \\
\hline
\end{tabular}

Erectile dysfunctions were also found in DM patients who was just recently diagnosed (8 respondents suffering from DM for 1-4 years). ED was typical in patients with DM for more than 8 years (19 people). Only 4 respondents experienced ED during their 5-8 years of DM period. The majority of the respondents from all of these categories (DM duration) experienced moderate dysfunction (44.2\%). No statistically significant correlation was found between DM duration and $\mathrm{ED}(\mathrm{p}=0.640$, Table 4).

Table 4. Correlation between DM duration and IIEF-5 scores

\begin{tabular}{|c|c|c|c|c|c|c|}
\hline \multirow[b]{2}{*}{$\begin{array}{c}\text { DM } \\
\text { Duration (years) }\end{array}$} & \multicolumn{5}{|c|}{ IIEF-5 Score } & \multirow[b]{2}{*}{$p$} \\
\hline & $\begin{array}{l}\text { Normal } \\
\text { n }(\%)\end{array}$ & $\begin{array}{l}\text { Mild } \\
\text { n }(\%)\end{array}$ & $\begin{array}{c}\text { Mild- } \\
\text { Moderate } \\
\text { n }(\%)\end{array}$ & $\begin{array}{c}\text { Moderate } \\
\text { n }(\%)\end{array}$ & $\begin{array}{l}\text { Severe } \\
\text { n }(\%)\end{array}$ & \\
\hline $1-4$ & $0(0 \%)$ & $2(5.9 \%)$ & $2(5.9 \%)$ & $4(11.8 \%)$ & $0(0 \%)$ & \multirow[t]{4}{*}{0.640} \\
\hline $5-8$ & $1(2.9 \%)$ & $1(2.9 \%)$ & $1(2.9 \%)$ & $2(5.9 \%)$ & $0(0 \%)$ & \\
\hline$>8$ & $2(5.9 \%)$ & $3(8.8 \%)$ & $2(5.9 \%)$ & $9(26.5 \%)$ & $5(14.7 \%)$ & \\
\hline Total (\%) & $3(8.8 \%)$ & $6(17.6 \%)$ & $5(14.7 \%)$ & $15(44.2 \%)$ & $5(14.7 \%)$ & \\
\hline
\end{tabular}

Erectile dysfunctions were found the most (29 respondents) in patients with $\mathrm{HbA} 1 \mathrm{c}$ levels of $>6.5 \%$. A large proportion of the respondents experienced moderate dysfunction $(44.1 \%$, Table 5). No statistically significant correlation was found between HbAlc levels and ED $(\mathrm{p}=0.611$, Table 5).

Table 5. Correlation between HbA1c levels and IIEF-5 scores

\begin{tabular}{|c|c|c|c|c|c|c|}
\hline \multirow[b]{2}{*}{ HbA1c Level } & \multicolumn{5}{|c|}{ HEF-5 Score } & \multirow[b]{2}{*}{$p$} \\
\hline & $\begin{array}{c}\text { Normal } \\
\text { n }(\%)\end{array}$ & $\begin{array}{l}\text { Mild } \\
\text { n }(\%)\end{array}$ & $\begin{array}{c}\text { Mild- } \\
\text { Moderate } \\
\text { n }(\%)\end{array}$ & $\begin{array}{c}\text { Moderate } \\
\text { n }(\%)\end{array}$ & $\begin{array}{l}\text { Severe } \\
\text { n }(\%)\end{array}$ & \\
\hline $4-5.6 \%$ & $0(0 \%)$ & $0(0 \%)$ & $0(0 \%)$ & $0(0 \%)$ & $0(0 \%)$ & \multirow[t]{4}{*}{0.611} \\
\hline $5.7-6.4 \%$ & $0(0 \%)$ & $0(0 \%)$ & $0(0 \%)$ & $2(5.9 \%)$ & $0(0 \%)$ & \\
\hline$>6.5 \%$ & $3(8.8 \%)$ & $6(17.6 \%)$ & $5(14.7 \%)$ & $13(38.2 \%)$ & $5(14.7 \%)$ & \\
\hline Total (\%) & $3(8.8 \%)$ & $6(17.6 \%)$ & $5(14.7 \%)$ & $15(44.1 \%)$ & $5(14.7 \%)$ & \\
\hline
\end{tabular}

\section{DISCUSSION}

This study revealed that most of the patients have experienced DM for more than 8 years. High HbA1c levels $(\geqslant 6.5 \%)$ were also found in a majority of the DM patients. Erectile dysfunctions in the patients were predominantly at a moderate level. Age and HbA1c levels seemed to be in line with ED. The older the patients and the higher the HbA1c levels, the more ED cases were found. However, no significant correlation was found between age, duration of $\mathrm{DM}, \mathrm{HbA1c}$ levels, and ED in the DM patients. The results of this study were similar to a previous study in Aceh [9]. This indicates that the risk of DM is higher in accordance with the aging process.
$\mathrm{DM}$ in the elderly indicates a disorder in the carbohydrate metabolism process. DM disorders include insulin resistance, loss of insulin release in the first phase, and an increase in postprandial glucose levels though with normal fasting glucose levels. Loss of insulin release in the first phase will result in failure of an initial increase in postprandial insulin. Among the three disorders, insulin resistance is the most significant. An imbalance between the amount of glucose and low ability of the body to respond to those conditions can induce DM in the elderly. In general, $\mathrm{DM}$ in the elderly is apparent in the changes in body composition characterized by decreased muscle mass and increased fat tissues. In addition, a decrease in the physical activities of the elderly can reduce sensitivity and several insulin receptors. Aging can also change plasma 
neurohormonal activities (IGF-1 and DHEAS). These processes can decrease the blood glucose uptake [3],[4].

One sexual problem frequently found in DM patients is sexual dysfunctions. Some DM patients have libido problems while some others do not. Male patients without libido problems will start having mild and moderate ED after several years of experiencing DM. Meanwhile, DM patients with libido problems can suffer from erectile dysfunctions (impotence) which precedes or coincides with DM symptoms [10]. The presence of impaired libido in DM patients is associated with hypogonadism and low testosterone levels. One study showed that $94 \%$ of ED cases were found in a group with hypogonadism. There is a significant decrease in the testosterone levels of DM patients with ED [11].

$\mathrm{DM}$ is the most common organic cause of ED in men [12]. In a study in Nigeria, $94.7 \%$ of type II DM patients (more than 57 years old) experienced ED (325 subjects in total) [13]. In line with this study, the majority of ED cases in DM patients were in the moderate category [14],[15]. The duration of DM is an important factor in ED. There is a positive correlation between the duration of DM and the occurrence of ED [16], [17],[18]. A symptom in the urinary system can also be found in DM patients with ED. Additionally, an increase in serum creatinine levels can occur [17].

Somatic and autonomic nerve dysfunctions and vascular disorders (microangiopathies) are the main pathogenesis of ED in DM. Approximately $70-80 \%$ vascular problems in DM patients who experience ED are strongly associated with atherosclerosis. Furthermore, occlusion of cavernous arteries also contributes to long-term sexual problems [8].

HbA1c levels are controlled for the DM conditions experienced by patients. Good control of DM can be observed from the HbA1c levels of less than $6.5 \%$. This study showed that the majority of the DM patients had poor control of DM conditions ( $>6.5 \%$ HbA1c levels). The results of this study are in line with a study conducted in Banda Aceh. Most of the patients with DM had high HbA1c levels $(84.7 \%$ with HbA1c levels of $>6.5 \%$ ) [9]. This indicates that in Indonesia DM patient compliance with the control of blood sugar levels remains low. In a study, poor control of blood glucose levels was dominant in patients experiencing DM for $>4$ years $(70.5 \%)$ [19].

HbA1c levels can be used to determine the glucose levels of DM patients in the last 1-3 months. HbA1c of $6 \%$ is equal to $126 \mathrm{mg} / \mathrm{dl}$ glucose concentration. Each $1 \%$ increase in HbA1c level equals $29 \mathrm{mg} / \mathrm{dl}$ glucose level [9]. A number of studies have indicated a significant correlation between HbAlc levels and blood glucose levels. Exacerbated glycemic levels lead to a corresponding increase in HbA1c levels. Therefore, high levels of HbA1c in DM patients can become an indicator of complications, such as ED.
The high HbA1c levels in this study are significantly related to ED. Anwar et al. showed that the majority of patients with ED fail to control their blood sugar levels [20]. In line with this study, high levels of HbA1c in DM patients can increase the risk of ED [15],[16],[18],[21],[22]. High levels of HbA1c followed by a long period of DM will create a conducive environment for microangiopathy and macroangiopathy. Microangiopathic conditions in DM patients are characterized by a smaller diameter of cavernous artery. Additionally, a low speed of systolic peak will increase the etiology of ED [17],[21],[23]. Psychological disorders, central nerves, androgen secretions, peripheral nerves, vascular endothelium, and disorders of smooth muscle contractility also increase the likelihood of erectile dysfunctions [23],[24].

This study shows a positive correlation between age, duration of DM, HbA1c levels, and ED using the IIEF-5 scores. Such results are also in line with the studies conducted in northern India [18] and China [16], indicating that in general the elderly with uncontrolled diabetes for a longer time will suffer from ED. Dodie et al. stated that patients with more than 5 years of DM will experience ED [8]. A study in Turkey also showed that age and duration of DM are crucial factors for ED. In patients with ED, the HbA1c levels also tend to be higher [25]. DM patients are likely to have uncontrolled hyperglycemic conditions which will further increase the damage to pancreatic beta cells. In the end, insulin secretion will become lower and lead to aggravated DM [26]. Contrary to the studies in northern India [18] and China [16], the results of this study indicate no significant relationship between the age, duration of DM, HbA1c levels, and erectile dysfunctions in type II DM patients. This is probably due to the limited number of subjects in this study and bias from the respondents when completing the IIEF-5 form provided. This information bias is likely associated with the Javanese culture that considers disclosure of information about sexual activities to be taboo.

Blood glucose levels are an important factor to prevent exacerbated DM conditions [27]. A longer period of hyperglycemia will result in a progressive cellular impact. Uncontrolled glucose levels in the blood can also damage neurons and endothelial blood vessels through an oxidative stress mechanism. Oxidative stress in the endothelium can interrupt the release/production of nitric oxide (NO) needed for vasodilation of blood vessels, especially in the genital organs. Consequently, erectile dysfunctions are found in patients with a long period of DM [21],[28].

A large number of factors affect the ability of patients to control their blood sugar levels. Patient's disobedience to a prescribed diet and a negative attitude towards DM are the main factor of failure to maintain normal blood sugar levels [26]. Male patients with type II DM should pay attention to the risk factors of ED. Regulation of blood glucose levels, testosterone levels, and peripheral artery disease are modifiable risk factors for patients [14]. Therefore, they 
should always have a routine examination to prevent DM complications.

This study has limitations in that a cross-sectional design is used to determine the correlation among the variables. Ideally, researchers should use a cohort design. However, this simple design can quickly describe the correlation between age, duration of diabetes, HbA1c levels, and the occurrence of ED in type II DM patients. Other limitations include the use of IIEF-5 for ED while a more objective parameter, such as Rigiscan [29] or Vibration Perception Threshold (VPT) [18], is preferable for ED detection in DM patients to minimize research bias.

\section{CONCLUSION}

There were no significant relationships between the age, duration of DM, HbA1c levels, and erectile dysfunctions in type II DM patients.

\section{AUTHORS' CONTRIBUTIONS}

NW planned the study design, analysed, interpreted the findings and manuscript drafting. DNA analysed, interpreted the findings, prepared the manuscript for publication and also the manuscript review. All of the authors have read and approved this manuscript. The authors declare no conflicts of interest in this study.

\section{ACKNOWLEDGMENTS}

The authors would like to thank the Faculty of Medicine of Universitas Islam Indonesia for funding this study.

\section{REFERENCES}

[1] R. Jindal, A. Siddiqui, and S. Wangnoo, "Classification and diagnosis of diabetes," Fundam. Diabetes, pp. 61-61, 2016, doi: 10.5005/jp/books/12733_7.

[2] R. K. Dasar, "Penyajian pokok-pokok hasil riset kesehatan dasar 2013," 2013.

[3] Indra Kurniawan, "Diabetes melitus tipe 2 pada usia lanjut," Public Health, pp. 576-584, 2010.

[4] S. Soelistijo et al., Konsesus pengelolaan dan pencegahan diabetes melitus tipe2 di Indonesia 2015. 2015.

[5] M. Sugiharso and M. Saraswati, "Hubungan disfungsi ereksi pada penderita diabetes melitus tipe 2 terhadap kualitas hidup di poliklinik penyakit dalam Rsup Sanglah Provinsi Bali," E-Jurnal Med. Udayana, vol. 5, no. 6, 2016.

[6] S. Gough and S. Manley, "HbA1c in Diabetes: Case studies using IFCC units,” p. 89, 2010.

[7] B. Timar and O. Albai, "The relationship between hemoglobin a1c and chronic complications in diabetes mellitus," Rom. J. Diabetes Nutr. Metab. Dis., vol. 19, no. 2, 2013, doi: 10.2478/v10255-012-0015-3.

[8] N. J. Dodie, L. Tendean, and B. Wantouw, "Pengaruh lamanya diabetes melitus terhadap terjadinya disfungsi ereksi," J. e-Biomedik, vol. 1, no. 3, pp. 1120-1125, 2013, doi: 10.35790/ebm.1.3.2013.3582.

[9] N. Ramadhan and N. Marissa, "Karakteristik penderita diabetes mellitus tipe 2 berdasarkan kadar Hba1C di puskesmas Jayabaru Kota Banda Aceh," Sel, vol. 2, no. 2, 2015, doi: 10.22435/sel.v2i2.4637.49-56.

[10] R. Harahap, "Disfungsi seksual pada penderita diabetes mellitus pria," Maj. Kedokt. Nusant., vol. 39, no. 3, pp. 5-8, 2006.

[11] S. Ghazi, W. Zohdy, Y. Elkhiat, and R. Shamloul, "Serum testosterone levels in diabetic men with and without erectile dysfunction," Andrologia, vol. 44, no. 6, pp. 373-380, 2012, doi: 10.1111/j.14390272.2012.01292.x.

[12] M. R., E. J., D. M., B. F., S. G., and M. F., "Prevalence of diabetes mellitus (DM) in a population of men affected by Erectile Dysfunction (ED)," Clin. Ter., vol. 166, no. 5, pp. 317-320, 2015, doi: 10.7417/T.2015.1885 LK

[13] F. O. Ugwumba et al., "Prevalence of, and risk factors for erectile dysfunction in male type 2 diabetic outpatient attendees in Enugu, South East Nigeria," Ann. Afr. Med., vol. 17, no. 4, pp. 215-220, 2018, doi: 10.4103/aam.aam_3_18.

[14] S. Nutalapati, S. C. Ghagane, R. B. Nerli, M. V. Jali, and N. S. Dixit, "Association of erectile dysfunction and type II diabetes mellitus at a tertiary care centre of south India," Diabetes Metab. Syndr. Clin. Res. Rev., vol. 14, no. 4, pp. 649-653, 2020, doi: 10.1016/j.dsx.2020.04.039.

[15] H. A., K. S., S. S.A., and A. M.G., "Evaluation of Erectile Dysfunction and associated factors in type-II diabetic patients in Birjand, Iran in 2008-2009," J. Res. Health Sci., vol. 11, no. 2, pp. 97-102, 2011.

[16] G. Yang, C. Pan, and J. Lu, "Prevalence of erectile dysfunction among Chinese men with type 2 diabetes mellitus," Int. J. Impot. Res., vol. 22, no. 5, pp. 310 317, 2010, doi: 10.1038/ijir.2010.21.

[17] A. Wiedemann, N. Meziane, J. Hirsch, and I. Fusgen, "Men with type 2 diabetes and erectile dysfunction are a particular risk group for LUTS - results of the witten diabetes survey," Aktuelle Urol., vol. 1, no. 4, pp. 280 284, 2012, doi: 10.1055/s-0033-1348243.

[18] A. Goyal, P. Singh, and A. Ahuja, "Prevalence and severity of erectile dysfunction as assessed by IIEF-5 in north Indian type 2 diabetic males and its correlation with variables," J. Clin. Diagnostic Res., vol. 7, no. 12, pp. 2936-2938, 2013, doi: 10.7860/JCDR/2013/7718.3777. 
[19] C. M. Astuti and A. Setiarini, "Faktor-Faktor yang berhubungan dengan pengendalian kadar glukosa darah pasien diabetes melitus tipe 2 rawat jalan di poliklinik penyakit dalam RSJ Prof.Dr.Soerojo Magelang Tahun 2013," Progr. Stud. Gizi, Fak. Kesehat. Masyarakat, Univ. Indones., 2013.

[20] Z. Anwar et al., "Erectile dysfunction: An underestimated presentation in patients with diabetes mellitus," Indian J. Psychol. Med., vol. 39, no. 5, pp. 600-604, 2017, doi: 10.4103/0253-7176.217015.

[21] M. A. El-Latif, A. A. Makhlouf, Y. M. Moustafa, T. E. Gouda, C. S. Niederberger, and S. M. Elhanbly, "Diagnostic value of nitric oxide, lipoprotein(a), and malondialdehyde levels in the peripheral venous and cavernous blood of diabetics with erectile dysfunction," Int. J. Impot. Res., vol. 18, no. 6, pp. 544-549, 2006, doi: 10.1038/sj.ijir.3901473.

[22] B. T.A., H. S., A. S., R. S., and M. A., "The impact of poor glycaemic control on the prevalence of erectile dysfunction in men with type 2 diabetes mellitus: a systematic review," JRSM Open, vol. 7, no. 3, 2016, doi: $10.1177 / 2054270415622602$ LK

[23] V. Tamás and P. Kempler, "Sexual dysfunction in diabetes," Handb. Clin. Neurol., vol. 126, pp. 223232, 2014, doi: 10.1016/B978-0-444-53480-4.000175.

[24] D. Dahril, Disfungsi Ereksi, vol. 1, no. September. 2017.

[25] M. Kiskac, M. Zorlu, M. Cakirca, B. Büyükaydin, C. Karatoprak, and E. Yavuz, "Frequency and determinants of erectile dysfunction in Turkish diabetic men," Niger. J. Clin. Pract., vol. 18, no. 2, pp. 209-212, 2015, doi: 10.4103/1119-3077.151043.

[26] M. Khattab, Y. S. Khader, A. Al-Khawaldeh, and K. Ajlouni, "Factors associated with poor glycemic control among patients with Type 2 diabetes," J. Diabetes Complications, vol. 24, no. 2, pp. 84-89, 2010, doi: 10.1016/j.jdiacomp.2008.12.008.

[27] L. Monnier and C. Colette, "Target for glycemic control: Concentrating on glucose.," Diabetes Care, vol. 32 Suppl 2, 2009, doi: 10.2337/dc09-s310.

[28] V. S. Thorve, A. D. Kshirsagar, N. S. Vyawahare, V. S. Joshi, K. G. Ingale, and R. J. Mohite, "Diabetesinduced erectile dysfunction: Epidemiology, pathophysiology and management," J. Diabetes Complications, vol. 25, no. 2, pp. 129-136, 2011, doi: 10.1016/j.jdiacomp.2010.03.003.

[29] D. P. Andersson, U. Ekström, and M. Lehtihet, "Rigiscan evaluation of men with diabetes mellitus and erectile dysfunction and correlation with diabetes duration, Age, BMI, Lipids and HbA1c," PLoS One, vol. 10, no. 7, 2015, doi: 10.1371/journal.pone.0133121. 